\title{
THE ROLE OF THE STRUCTURES ON THE FLUORITE MINERALIZATION: INSIGHT TO FLUID INCLUSION AND ALTERATION MAP OF THE LAAL-KAN FLUORITE DEPOSIT, NW IRAN
}

\author{
Mahdi BEHYARI *, Mansour REZAEI AZIZI and Ali ABEDINI \\ Department of Geology, Faculty of Sciences, Urmia University, 5756151818, Urmia, Iran
}

*Corresponding author's e-mail: m.behyari@urmia.ac.ir, m.behyari@gmail.com

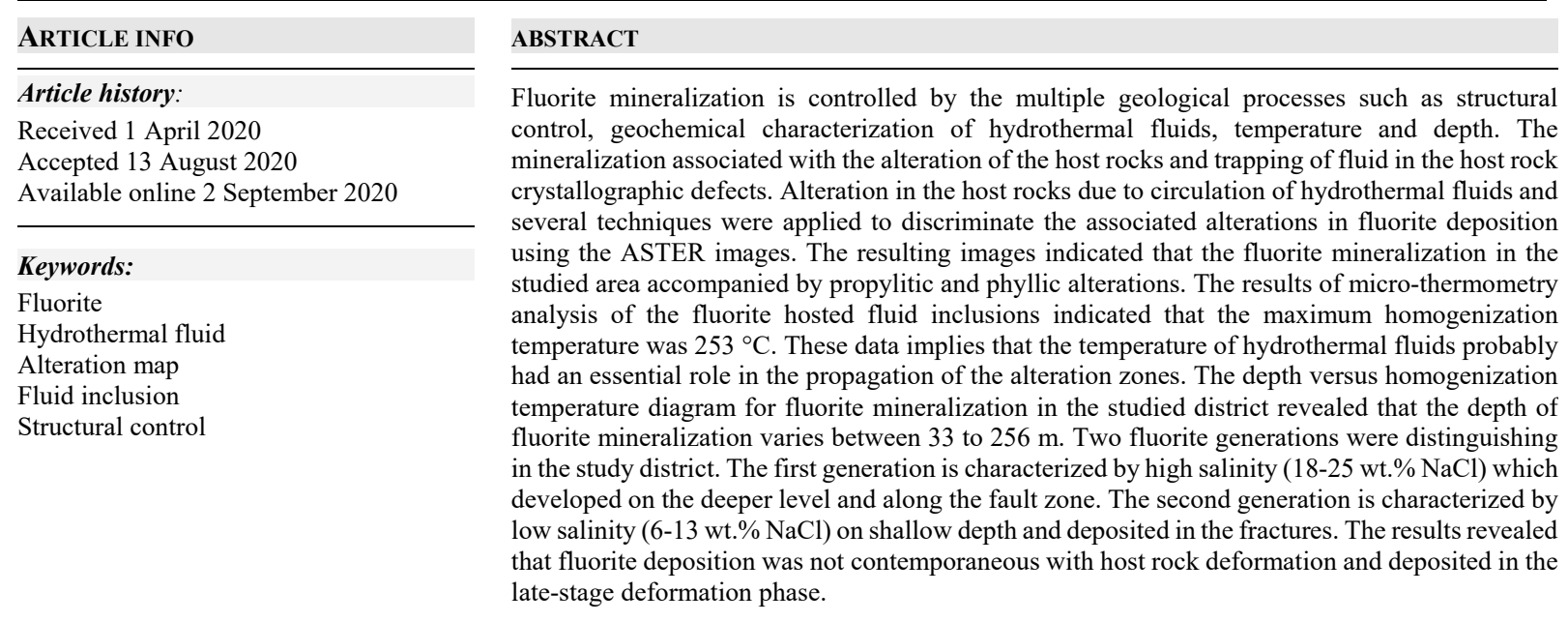

\section{INTRODUCTION}

Ductile and brittle shear zones in the Zagros orogeny developed as a result of the continental collision of the Arabian plate with the Iranian microcontinent (Sarkarinejad and Azizi, 2008; Mouthereau et al., 2012; Behyari and Kanabi, 2019). These events caused the evolution of the three major structural zones consisting of the Zagros Fold and Thrust Belt (ZFTB), Sanandaj_Sirjan Metamorphic Zone (SSMZ) and Urmia-Dokhtar Magmatic Arc (UDMA) (Fig. 1) (Berberian and King, 1981; Alavi, 1994; Ghasemi and Talbot, 2006; Mouthereau et al., 2012). Continuity of northward movement of the Arabian plate caused to increase structural deformation and permeability of host rocks (Vernant et al., 2004; Djamour et al., 2011). The magmatic activities in the UDMA acted as a thermal source of hydrothermal fluids, which usually associated with considerable ore mineralization (Hassanzadeh et al., 2008; Zarasvandi et al., 2014; Zhang et al., 2018; Behyari and Shahbazi, 2019). The host rock structures had an essential role in the emplacement of ore bodies in this region. The fluorite veins considered as low-temperature deposits (Zou et al., 2020a). The development of these deposits have a close relationship with the hydrothermal magmatic activity and controlled by the structural elements of the formation environment (Alipour et al., 2015; Zou et al., 2016; Zou et al., 2020b). Based on the formation, fluorite deposits classified into two groups. The first group is fluorite veins developed in the sedimentary carbonate host rocks and accompanied with the lead and zinc mineralizations. The second one deposited in the alkaline and per-alkaline volcanic rocks (Richardson and Holland, 1979; Jébrak, 1997; Magotra et al., 2017; Kraemer et al., 2019).

Structural evolution during transtension and transpression regimes were documented in the Zagros suture zone (Mohajjel and Fergusson, 2000; Mohajjel and Rasouli, 2014; Behyari and Kanabi, 2019). Dilatational fracture evolved in these conditions may be filled by mineral aggregation that mostly precipitated from the hydrothermal fluid (Fischer et al., 2009; Aliyari et al., 2012; Alizadeh-Dinabad et al., 2013; Almasi et al., 2017). The structural characterization of host rocks directly related to the propagation and concentration of veins. Geochemical properties of the veins are also related to the composition of hydrothermal fluid that the veins 


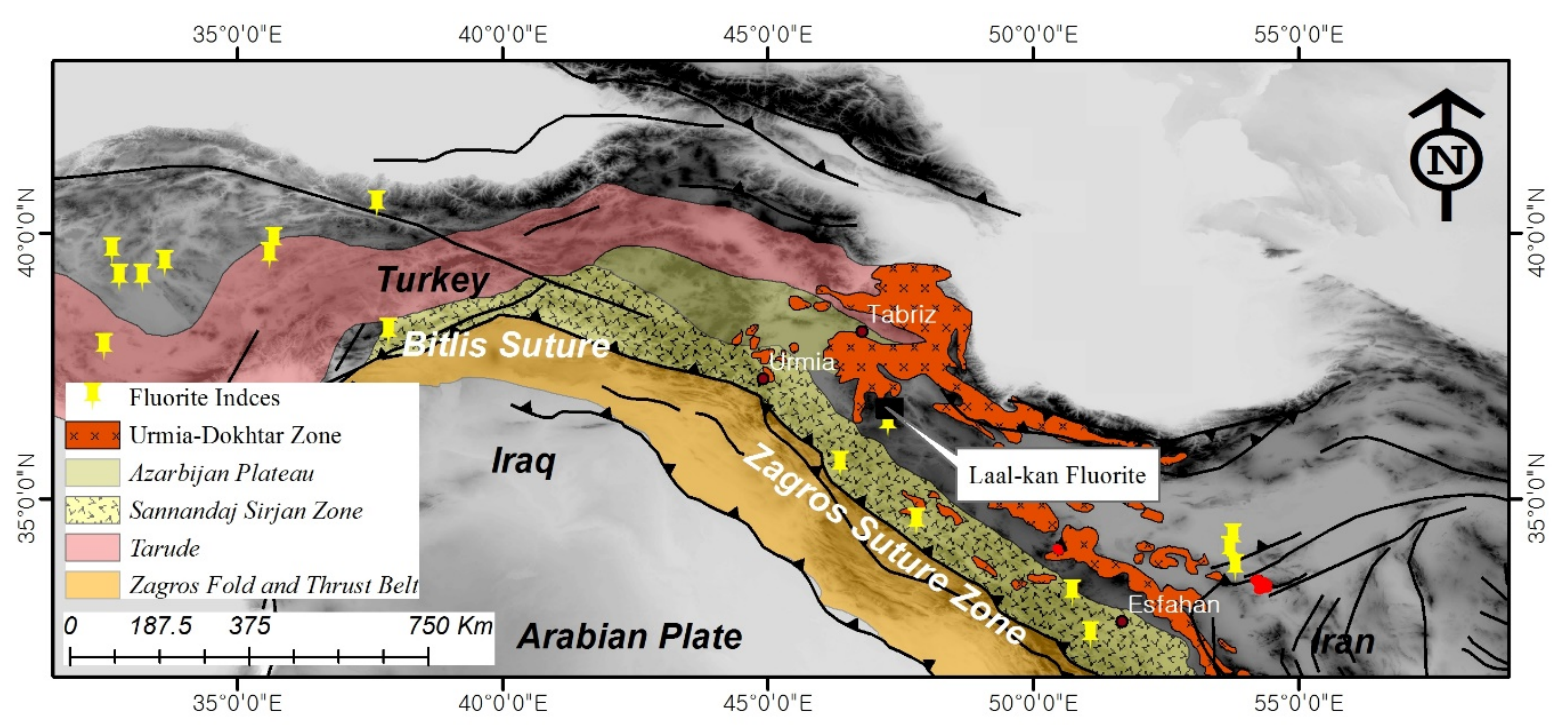

Fig. 1 The regional map of the study area and the distribution of fluorite indices. The map depicted a major structural zone in the Zagros Orogeny. The location of the studied regions is shown by the black rectangle and some fluorite indices distribution by the yellow pin.

deposited from (Alipour et al., 2015; Parsa et al., 2016; Zou et al., 2016; Ehya and Mazraei, 2017; Zou et al., 2017), thus the veins can provide valuable data about the geological history of the deformed crust. The structure of veins can be used for distinguishing the relative age of the deformation phase as well (Behyari and Shahbazi, 2019). The veins mostly containing fluid inclusion, these features give useful information about the temperature, pressure and depth of vein formation and can be shed light on the tectonics evolution of deformed terrene (Zou et al., 2016; Baharvandi et al., 2017; Ehya and Mazraei, 2017; Kraemer et al., 2019).

In this research, a fluorite deposit in the NW Iran investigated for evaluating the effect of the structural controls on low-temperature ore depositions. To better understanding, the role of structural geometry in fluorite mineralization, remote sensing technique and the structural analyses were used. Fluid inclusions data used for characterizing the hydrothermal fluids such as the source of fluids, temperature and depth of deposition. The main aim of this research is to discuss the role of structural elements in the evolution of lowtemperature hydrothermal systems.

\section{GEODYNAMICS AND GEOLOGICAL SETTING:}

The LK fluorite deposit situated near the Sanandaj-Sirjan Zone (SSZ) and Urmia-Dokhtar magmatic arc (UDMA) boundary, almost $500 \mathrm{~m}$ north of the Angouran $\mathrm{Zn}-\mathrm{Pb}$ deposit (Gilg et al., 2006b; Daliran et al., 2009). The UDMA has been developed parallel to the Zagros Fold Thrust Belts (ZFTB) during the Eocene-Miocene and host some porphyry $\mathrm{Cu}$ deposits (Zarasvandi et al., 2015). The SSZ is a polyphase deformed zone developing between the
ZFTB and UDMA. The tectonostratigraphy of this zone includes the Paleozoic to the Cretaceous sedimentary and metamorphic rocks, which thrust on ZFTB (Alavi, 1991; Agard et al., 2011; Mouthereau et al., 2012). The evidence of the Neo-Tethys oceanic crust subduction initiation to final closure recorded in this region and characterized by the poly-deformed metamorphic rock units that affected with deformed and undeformed plutons (Allen and Amstrong, 2008; Rezaei Azizi et al., 2018a; Zhang et al., 2018). The age of plutonism in the study district varied in a wide range that is one of the controversial subjects in the Zagros geodynamic evolution history. These magmatic activities can be divide into three major categories. The first set is the Upper Neoproterozoic-Cambrian age intrusion that emplaced during proto-Tethys postcollisional magmatic activity (Hassanzadeh et al., 2008; Moghadam et al., 2015; Badr et al., 2018). The second set is the Jurassic plutons that are affinities to the initial subduction of the Neo-Tethys oceanic crust or development of slab window in the subduction zone (Azizi et al., 2015; Zhang et al., 2018), and the youngest set intruded in the Paleocene-Eocene as a result of ridge spreading in the collision zone (Zhang et al., 2018). This plutonism in the different stages act as thermal engines for propagation of metamorphism, deformation and the mineralization. Previous studies indicated that fluorite deposits are almost situate near the margin of the SSZ and UDMA. In the studied district also an observable footmark of plutonism is distinguished (Rezaei Azizi et al., 2017).

The oldest rock units in this area consist of a sequence of metamorphic rocks such as quartziteschist, amphibolite, gneiss, mica-schist, and marble (Peksh) of the Neoproterozoic age. Previous dating studies indicated that these rocks has been 


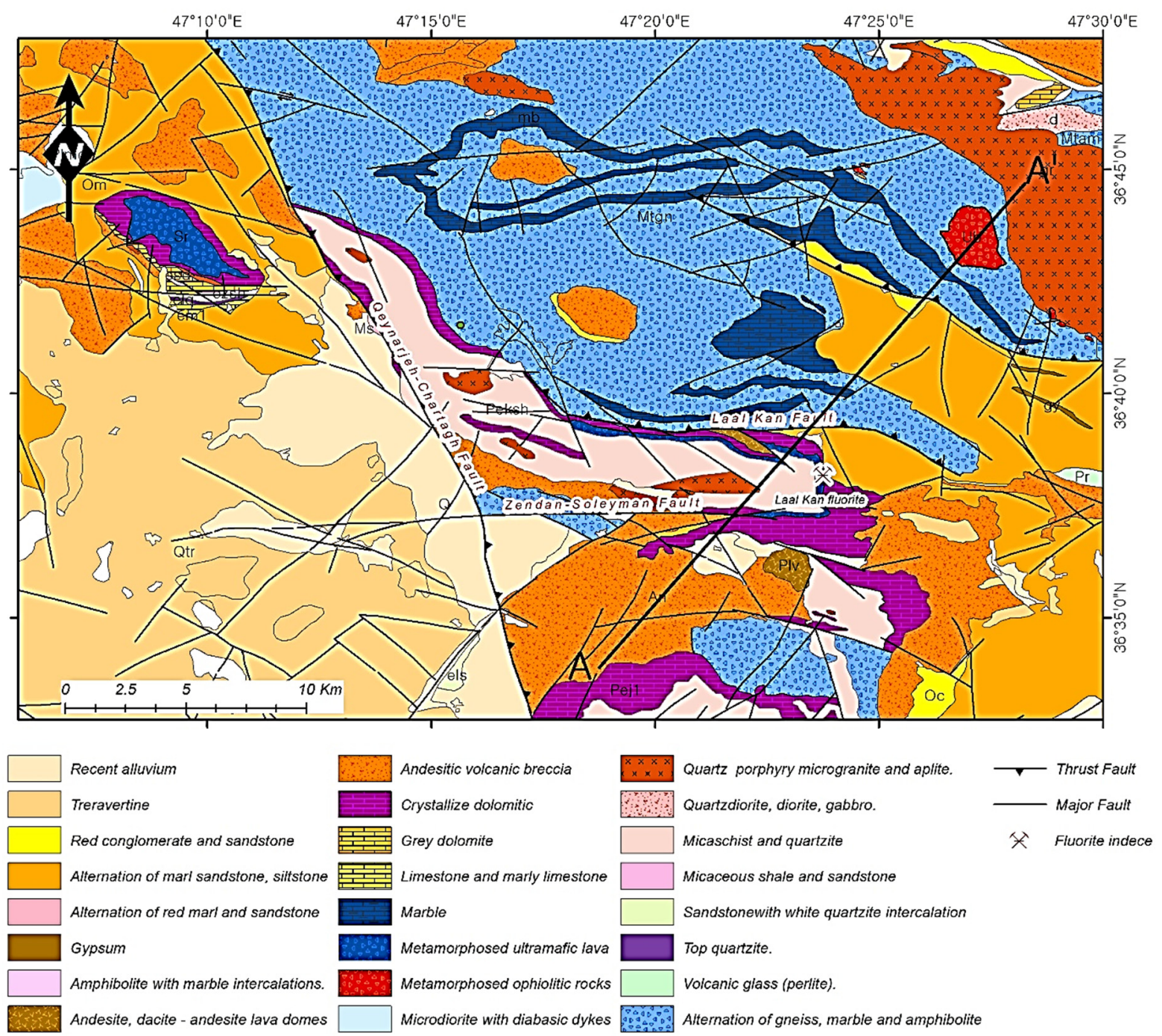

Fig. 2 The simplified geology maps of the studied district.

metamorphosed during Alpine orogeny (Daliran et al., 2009). Field observations indicate that the marble units $(\mathrm{mb})$ in this district are characterized by small to large cavities due to dissolution processes under supergene conditions. With attention to the microfauna in the marble unit, it can be concluded that the age of this unit is Neoprotrezoic to Lower Cambrian (Hamdi, 1995). An outcrop of highly metamorphosed rocks, including muscovite, feldspar, garnet, and ophiolite assemblage of Paleozoic age, also covers the northern part of the area (Mtgn). Granite and quartz diorite-gabbro of the TriassicJurassic age also crop out at the northern part of the Zendan-Soleyman Fault. (Gilg et al., 2006b) suggested that formation of the lower red formation, including red sandstones, conglomerates and gypsiferous marls, have been developed during the Late Paleogene-Early Neogene in this area, which is followed by igneous systems including ignimbrites, tuff volcanic breccia and andesite bodies. These units were overlaid by limestone of the Qom Formation. The existence of thermal spring shows the volcanic and geothermal activities in this district. Due to presence of thermal spring, many travertine terraces and carbonate deposit are observed along and, or parallel to the Zendan-Solayman Fault. Meanwhile, other Quaternary sediments such as sand, clays, and alluvium cover some parts of this district (Fig. 2).

\section{MATERIAL AND METHODS}

In order to better constrain the structural controls on the fluorite deposition in the studied regions, three approaches applied to collecting data: (1) Structural analysis was carried out based on field observation and microstructural analysis of ore body and host rock. A detailed field survey was conducted for the demonstration of the attitude and geometry of faults and fractures. The structural pattern are essential factors to increase the permeability of metamorphic units and create passways for uprising hydrothermal 

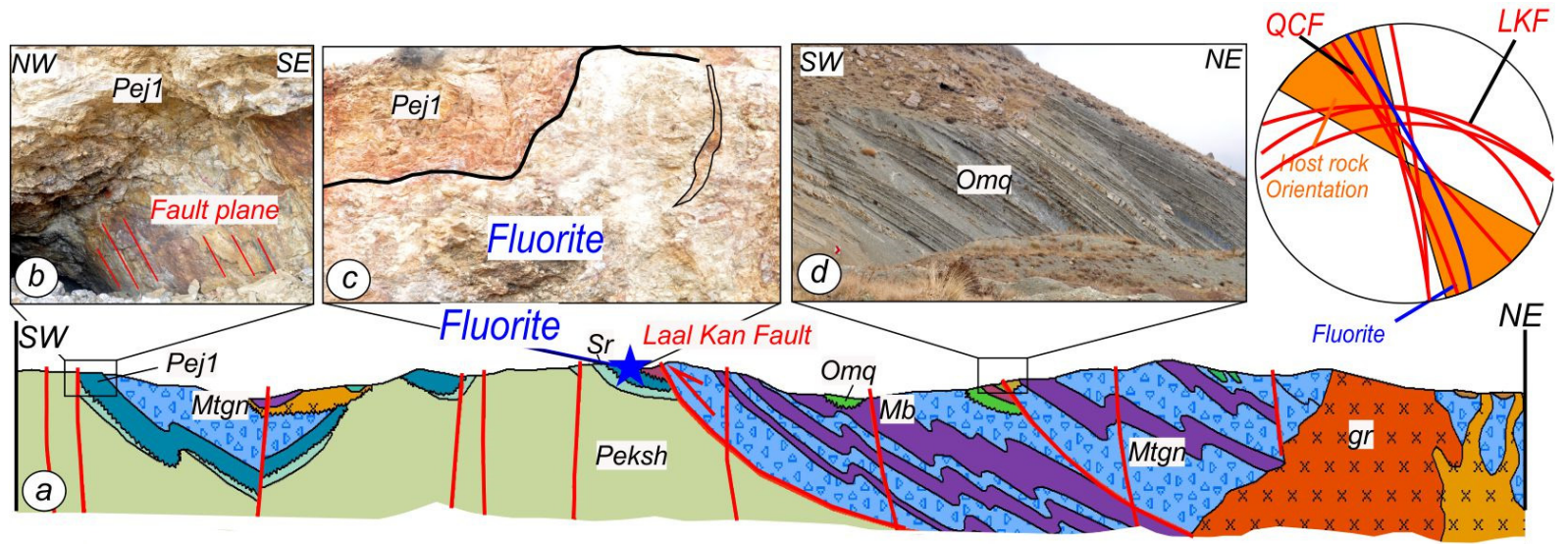

Fig 3 a) The Cross section of the LK region with stereoplot of the host rock orientation fluorite vein attitude and major structural elements orientation, b) LK fault plane with stretching lineation, c) Emplacement of fluorite vein in the host rocks and d) Bedding orientation in the Miocene sedimentary basin.

F-rich fluids. (2) Remote sensing analysis was carried out to obtain a fracture density map as a method to reveal the effect of fractures on hydrothermal processes and fluorite deposition. (3) Fluid inclusion analyses for estimation the least temperature of the mineralization.

\subsection{STRUCTURAL ANALYSIS}

In the LK region, the contact zone between fluorite mineralization and host rocks is relatively sharp, with no significant alteration. Therefore, it revealed that the structural features have probably played an important role during penetration of low $\mathrm{pH}$ meteoric waters and then uprising F-rich fluids that responsible for the deposition of the fluorite and $\mathrm{Zn}-\mathrm{Pb}$ as well (Gilg et al., 2006a; Daliran et al., 2013). The litho-type of the LK region comprises of two distinct groups: the first group consists of the Precambrian basement that can be divided into two forms including the metamorphic and nonmetamorphic sequences and the second one is the young sedimentary succession. These three lithological zone boundaries coincide with the major fault systems in the studied district (Fig. 3a). The Laalkan Fault (LKF) is located adjacent to the fluorite indices. The general trend of the LKF is E-W $\left(\mathrm{N} 80^{\circ} \mathrm{W} / 60^{\circ} \mathrm{NE}\right)$ but, have been affected by another fault system in the western termination under effecting of and rotated to NW-SE attitude $\left(\mathrm{N} 40^{\circ} \mathrm{W} / 40^{\circ} \mathrm{NE}\right)$ (Fig. 3b). The fault plane dip varies in a wide range that, in some exposures it can be seen vertically whereas, to the western termination, the dip of the fault plane decreased to $40^{\circ}$. Along this fault, gneiss (Mtgn) as deformed basement on the hanging-wall thrust on the younger schist unit (Peksh) of the foot-wall (Fig. 3c). Another important fault in this region is the Qeynarjeh-Chartagh Fault (QCF) with the NNW-SSE strike and the fault dip near to vertical toward NE. The kinematic of this fault is not clear, and three different hypotheses exist. Some authors considered it as a normal fault and boundary of the Miocene sedimentary basin (Fig. 3d) with the deformed basement of the Precambrian (Moghadam et al., 2016), and the others regarded it as a strike-slip fault with $15 \mathrm{~km}$ right-lateral displacement (Allen et al., 2011) whereas, some researchers admitted with the reverse movement (Saki, 2010).

The Laal-kan fault had played a significant impact in the fluorite deposition. Fault rocks in this zone composed of broken fragments gneiss and marble units. The host rock micaceous schist unit general trend is NW-SE, and fault attitude is E-W, and the intersection point of the host rock and fault zone coincide to the fluorite concentration.

\subsection{THE MICROSTRUCTURE OF HOST ROCK AND ORE DEPOSIT}

The microstructures evolution affected by the deformation conditions such as temperature, pressure, the presence of fluid, and the rheology of grains. Therefore, the microstructures used as an indicator for evaluation of the deformation conditions (Watts and Williams, 1983; Behyari and Shahbazi, 2019). Microstructures analysis conducted in the host rocks and ore body in the studied districts.

The micaceous schist unit in the LK hosts the fluorite mineralization. The quartz grains are the dominant mineral phase that has a distinct preferred orientation. The other mineral phases comprise biotite and muscovite, which caused the preferred orientation and development of the foliation in the host rocks. The primary foliation of the micaceous schist was folded and propagated a secondary crenulation. The axial plane of these crenulations caused to the constituted second generation foliation. These structures have been formed under the regional metamorphism regime and ductile conditions (Fig. 4a). The fluorite samples in the LK region are the coarse-grained with distinctive cleavage. The microstructure analysis revealed that fluorite mineralization has probably 

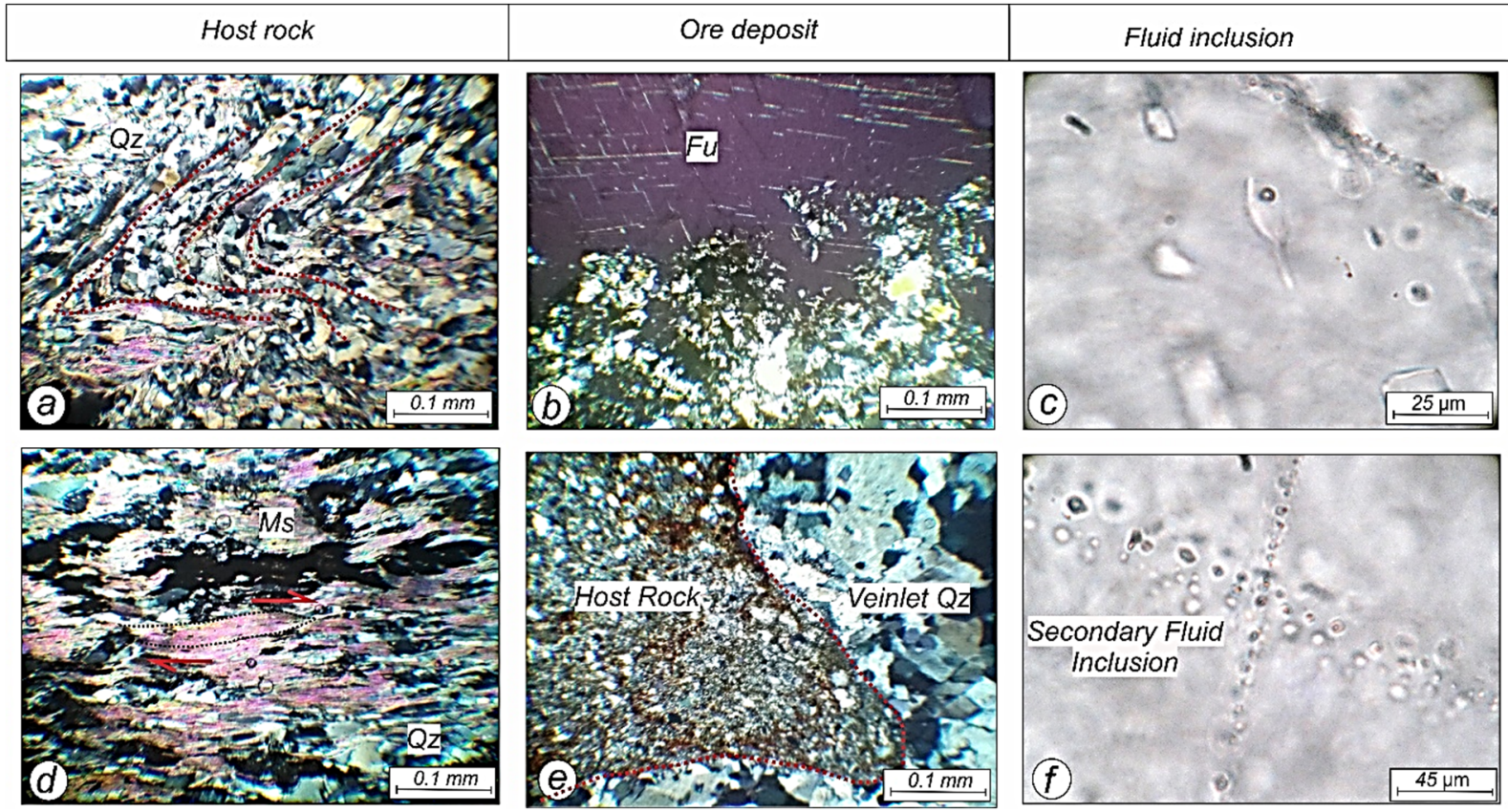

Fig. 4 Microstructures of the host rocks and ore body in the studied regions. a) Crenulation formed under ductile conditions and regional metamorphism régime. b) The early-stage fluorite confined with the quartz matrix. c) The trapped fluid inclusion geometry. d) Mica-fish structure developed under the dextral shearing régime.

occurred in two different stages, including early and late stages. The early-stage fluorite formed within a quartz matrix, the evidence of quartz recrystallization such as bulging observed in the thin section (Fig. 4b). These fluorites also deformed and propagated brittle fractures, which displaced primary cleavage and open spaced filled by the fine grain quartz or micritic calcite. The late-stage fluorite has been formed in the open spaced and fractures inside the early stage fluorites. The brittle fracture concentration indicate that this generation of fluorites was formed in the low- temperature. The paragenesis of barite with the late-stage fluorite in the LK region also implies the low-temperature $\left(75^{\circ} \mathrm{C}\right)$ of the mineralization condition during the late stage of mineralization (Uras et al., 2017). Fluid inclusions as the ore-bearing fluids trapped in the defect of the crystallographic networks were studied as an effective method for micro-scale analysis (Fig. 4c). The mica fish structure developed by dextral shearing of muscovite grain during progressive deformation. Penetrative spaced foliation in the host rock consists of flattened quartz in the microlithon and sheared muscovite in the cleavage domain (Fig. 4d). These structures in the host rock revealed that non-coaxial deformation was dominant regime in the studied region. Quartz and fluorite veins have been mostly developed along the fractures of the host rocks. The quartz grains are mostly undeformed, and there is no evidence of recrystallization in the grains boundaries (Fig. 4e). This evidence indicated different deformation history of host rock and fluorite veins.
The secondary fluid inclusions in the straight row formed along the micro-fractures (Fig. 4f) and hydrothermal fluid circulated in the host rocks and deposited the fluorite in the fractures.

\subsection{FRACTURE DENSITY MAP}

The results of structural and microstructural analysis showed that the fluorite deposits directly related to the fractures. DEM and ASTER satellite image was used for the extraction of fracture pattern in the studied districts (Behyari et al., 2019). Some parameters such as filter radius, edge gradient threshold, curve length threshold, line fitting error, angular difference and linking distance threshold define the lineament extraction in the Geomatica software (Ramli et al., 2010; Thannoun, 2013). The extracted lineament was converted to the shapefile and processed in the Arc Map software. In the next step the lineament spilt to the vertices and assigned latitude and longitude each vertices and the fracture density map produced for studied regions. The extracted vertices were converted to the DXF file, and the rose diagram of lineaments was derived with using of the Rockwork software. The fracture density map depicted and the concentration of fractures and rose diagram reveal the fracture sets the orientation (Behyari et al., 2019).

\subsection{IMAGE PROCESSING AND REMOTE SENSING}

The hydrothermal fluid flow in the fault zone and fractures caused the host rocks altered. The alteration is the clue for the mineral exploration or distinguishing 
the effective structures in the studied region (Behyari et al., 2019). Regarding to the studied areas broadness, direct investigation of alteration zones is timeconsuming, therefore, applied the remote sensing technique facilitates to the discrimination of the alteration zone (Abdeen et al., 2001). In this study, Aster satellite images were used for the extraction of alteration zones.

The different methods are used for the satellite image processing, which the most important are as follows: increasing contrast with histogram, edge enhancement, a pseudo-color composite image, band ratio (BR), principal component analysis (PCA), and spectral angle mapper (SAM). Pseudo-color composite image, BR, PCA, SAM methods were used for discrimination of alteration zones associated with fluorite deposition in the studied district (Crosta et al., 2003; Shahriari et al., 2015).

The one band data is not enough for distinguishing targets on the satellite image. Due to the multispectral nature of the satellite images, the conventional method is producing a color composite image (Tangestani et al., 2011; Rajendran et al., 2012). Three bands of satellite image coevally display red, green, and blue channels caused to the detection of the most targets. The experimental analysis indicated that the most appropriate color composite image for the detecting of alteration zones is the $\mathrm{RGB}=4,6,8$. The index minerals for propylitic zone (epidote and chlorite), argillic zone (alunite, kaolinite) and phyllic zone (illite, muscovite) are shown by green, red and blue color, respectively (Abdeen et al., 2001; Amer et al., 2010).

The band ratio is one of the common methods applied for the detection of alteration zones. This technique helps to eliminate the topographic effect and shadows from satellite images (Gabr et al., 2010). Meanwhile, the lithological boundary becomes sharper with the ascending of contrast in the lithological margin. The band ratio is calculated by dividing the amount of $\mathrm{DN}$ in each pixel from one band to DN value on the other band (Di Tommaso and Rubinstein, 2007). The most critical issue in this method is the selection of the appropriate bands. The proper band is the band that has the biggest difference in absorption and reflection of wavelength. The reflection and absorption bands put on the numerator and the dominator, respectively. In the resulted grayscale image, the white color indicates the target layer. To detecting of the alteration zones near fluorite mineralization, the indices minerals reflection, and absorption bands were used which, the ratio for phyilic zone, argillic zone and propylitic zone are $(5+7) / 6$, $4 / 5$, and $(9+7) / 8$, respectively (Di Tommaso and Rubinstein, 2007; Gabr et al., 2010).

For the better detection of alteration zones that is accompanied by fluorite mineralization, the SWIR region of the ASTER satellite image was analyzed by principal component analysis (PCA) image processing methods. In this technique, the main goal is the compression of multispectral data to reduce unnecessary information.

For discrimination, the propylitic alteration, bands 9 and 7, is reflection and band 8 is absorption. Analysis of the PC indicated that PC4 is the proper component in this $\mathrm{PC}$ bands 7 and 9 have positive value, unlike band 8 . In the phyllic alteration bands 5 and 7 is reflection and band 6 is absorption surviving of PC showed the PC5 is suitable for discrimination of this alteration and finally for the argillic alteration detection applied PC3. In the result images, the white pixel is the indicator of target index minerals for the alteration zone. The RGB color image was produced with assigning the propylitic alteration for the green channel, argillic for the red channel and phyllic for the blue channel. This mage depicted the propagation of alteration zones in the studied districts.

Spectral Angle Mapper (SAM) is another technique applied for mapping of the altered minerals associated with fluorite mineralization (Girouard et al., 2004). This method is an efficient supervised classified method for comparing the spectral of images with standard spectral library or reference spectral. The SAM algorithm analyzed the similarity of the two spectral by calculating the angle between two bands. This angle changes between 0 to 1 and will be more accurate detection in the lower angle, if the angle is 1 , the entire image identified as the target minerals. For detecting the optimized angle to extract alteration, we use $(\bar{x}-2 s)$ method.

\subsection{FLUID INCLUSIONS MICRO-THERMOMETRY:}

The depth of mineralization can be estimated with attention to the temperatures and fluid inclusion provides valuable data about the trapping temperature of the fluid inclusion in the crystallographic defects (Fang et al., 2020). The homogenization temperature (TH) for the fluid inclusions was recorded during the heating process using a Linkam THMS-600 device with TMS94 (heating stages). The result of fluid inclusions was used to estimate the depth of mineralization.

\section{RESULT AND DISCUSSION}

Our structural analysis revealed that the LK region deformation have been probably occurred in the three phases (D1 to D3). The first generation of foliation (S1) developed coetaneous with the D1 phase. The compositional layering of the quartz-rich and biotite rich zone created disjunctive foliation morphology. Deformation intensity eliminated the original layering trace $(\mathrm{S} 0)$.

D2 phase caused to evolution of (S2) foliation, the spatial orientation of the foliated plane is $\mathrm{N} 70^{\circ} \mathrm{W} / 50^{\circ} \mathrm{NE}$, this attitude is similar to the LKF, therefore: we assumed this fault propagation are contemporaneous with D2 deformation phase. After widespread foliation, the folds are the dominate structure that developed in this phase, and it can be seen in both of microscopic and outcrop scale. Mostly 

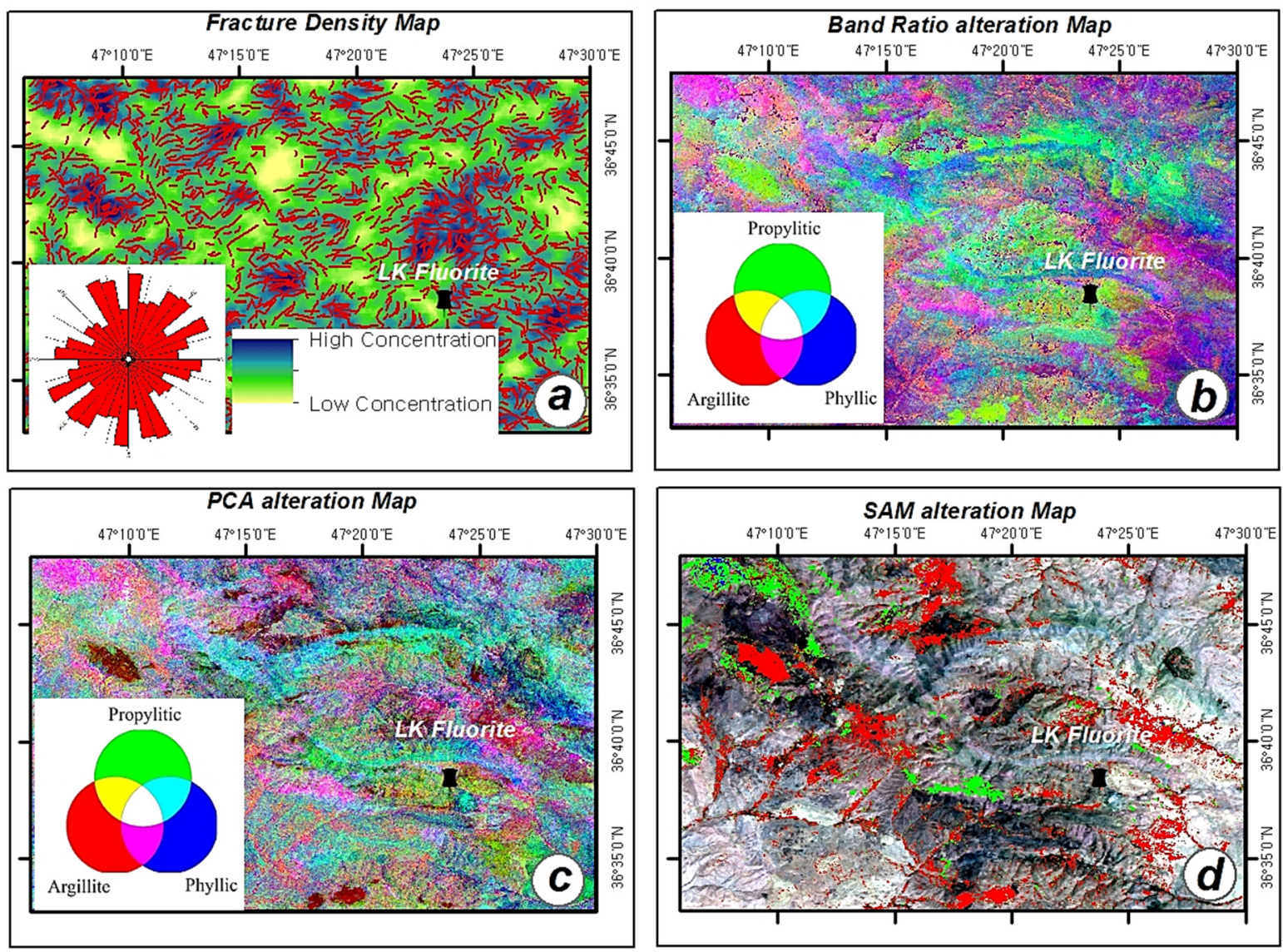

Fig. 5 Remote sensing analysis results in the LK region. a) Fracture density map, Fracture spatial orientation, and joint sets number extracted from the ASTER satellite image. b) Aster RGB band ratio image R: 4/5, G: 9+7/8, B: 5+7/6. RGB image indicated propylitic and phyllic alteration with fluorite mineralization. c) The RGB image of PC3, PC4 and PC5 of PCA bands of the study area. d) Spectral angle mapper, the maximum angle applied: 0.21 for kaolinite, 0.16 for chlorite, 0.14 for calcite and 0.15 for the illite.

the folds are overturned or recumbent folds. The axial plane attitude is NW-SE, and dip is toward NE, and the fold axis is horizontal.

The D3 phase is a brittle deformation and, in the outcrop, scale followed by oblique-slip N-S direction faults. The faulting mechanism is the right-lateral with a reverse component. The structures that develop in this stage cut the older structure, for instance, QCF cut and dextrally displaced LKF.

The fluorite host rock main structure is folded rocks, and it seems developed in the D2 phase however the orientation of fluorite bearing veins is NNW-SSE direction and brittle cataclastic fracture developed in the microstructure, this evidence showed the mineralization in this region is related to the D3 deformation phase.

The deformation conditions of host rocks are entirely different from fluorite deposits. The polyphase deformation of host rocks implies to the regional deformation and high-temperature conditions, but brittle fracturing in fluorite indicated the low-temperature condition.

The superimposition of different deformation phases caused to the complexity of the structural pattern. The fractures orientation change in the board range and fractures with $\mathrm{N}-\mathrm{S}$ direction is the dominant set and NE-SW is the second-order fractures set (Fig. 5a). The fracture orientation and fluorite mineralization trend are not in the same direction and fluorite deposited in the E-W trend. The N-S oriented fractures cut the fluorite veins and it seems that these fractures are related to the subsequent deformation phase.

The RGB band ratio map revealed the propylitic alteration that assigned in the green channel is the dominant alteration zone, and phyllic alteration propagated as a subsidiary alteration around the fluorite index (Fig. 5b). The principal component matrix analysis revealed that propylitic alteration has a maximum data in the $\mathrm{PC} 4$, argillic alteration in the PC3 and phyllic alteration in PC5. The color distinction of the alteration zone provides by extracting an RGB image by assigning PC4 to the green channel, PC3 to the red channel, and PC5 to the blue channel. The resulted image in the LK region revealed that the fluorite deposition in this district discriminated with propylitic, and phyllic alteration (Fig. 5c). Finally, in order to better evaluation of the 

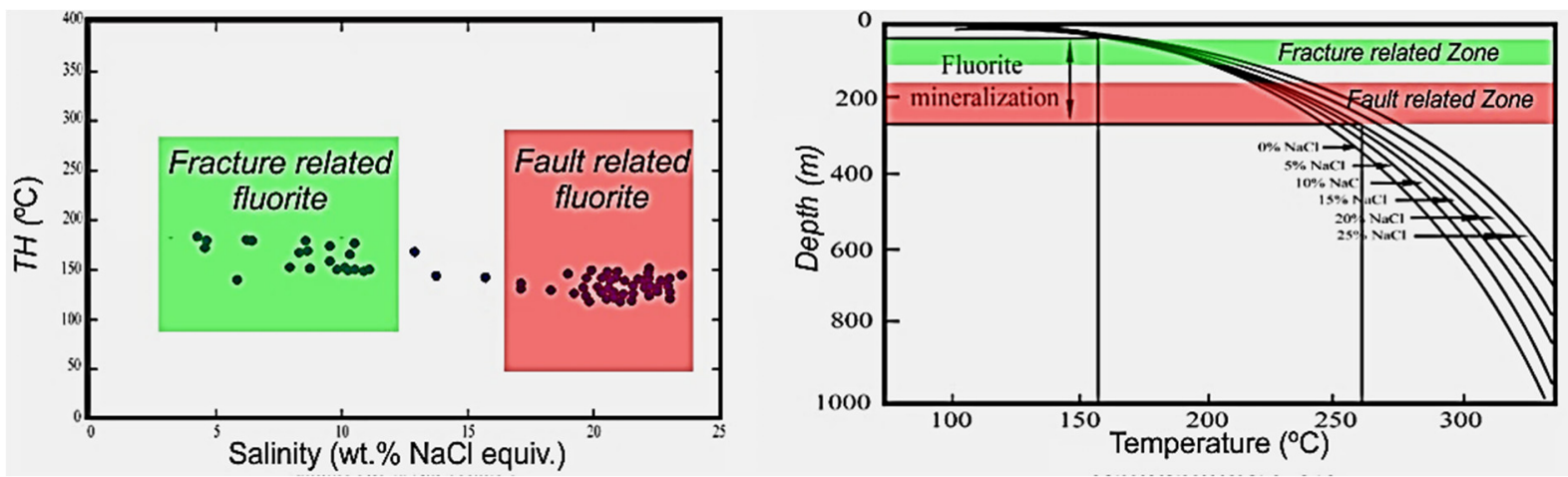

Fig. 6 a) Salinity respect to temperature in the three studied districts. b) The depth versus homogenization temperature diagram for fluorite mineralization in the study district.

Table 1 The results of micro-thermometry in fluorite mineralization events of the study district. $T_{e}=$ eutectic temperature; $\mathrm{T}_{\mathrm{H}}=$ homogenization temperature; $\mathrm{N}$ refers to number of measured fluid inclusions.

\begin{tabular}{|c|c|c|c|c|c|c|c|}
\hline District & mineral & $\begin{array}{c}\text { Fluorite } \\
\text { Color/Generation }\end{array}$ & $\begin{array}{c}\text { Fluid } \\
\text { inclusion } \\
\text { phases }\end{array}$ & $\mathrm{T}_{\mathrm{e}}\left({ }^{\circ} \mathrm{C}\right)$ & $\begin{array}{c}\text { Salinity } \\
\text { (NaCl Equiv. } \\
\text { wt.\% ) }\end{array}$ & $\mathrm{T}_{\mathrm{H}}\left({ }^{\circ} \mathrm{C}\right)$ & $\mathrm{N}$ \\
\hline \multirow{7}{*}{ Laal-kan } & Fluorite & Blue-green & L-V & $-51 /-18.5$ & $2.4-13.49$ & $158-251$ & 19 \\
\hline & Fluorite & Purple & L-V & $-47 /-17.8$ & $5.8-11.7$ & $179-246$ & 17 \\
\hline & Fluorite & Colorless & L-V & $-48 /-18.4$ & $2.9-10.8$ & $169-253$ & 15 \\
\hline & Fluorite & First generation & L-V & $-75 /-63$ & $15.8-20.8$ & $128.5-139.5$ & 16 \\
\hline & Fluorite & Late generation & $\mathrm{L}-\mathrm{V}$ & $-62.5 /-52$ & $7.9-15.8$ & $140-152$ & 19 \\
\hline & Fluorite & First generation & L-V \& L-V-S & $-52.5 /-36$ & $19.2-23$ & $118-151$ & 27 \\
\hline & Fluorite & Late generation & L-V \& L-V-S & $-47 /-17.8$ & $18.9-23.5$ & $121-147$ & 22 \\
\hline
\end{tabular}

alteration zone propagation, supervised classification method and spectral angle mapper (SAM) were used. The optimum angle calculated with $(\overline{\mathrm{x}}-2 \mathrm{~s})$ method in the propylitic alteration zone is equal to 0.14 for calcite and 0.16 for chlorite, whereas, in the argillic zone this angle is equal to 0.21 for the kaolinite and in the phyllic zone equal to 0.15 for the illite (Fig. $5 \mathrm{~d}$ ). The multiple angle value for the indices minerals of the alteration zone indicated in the LK region lowtemperature hydrothermal fluid altered micaceous country rocks and fluorite mineralization accompanied by propylitic and phyllic alteration.

Microthermometric and petrographic of fluorite hosted fluid inclusions analyzed in the seven samples of the studied districts. Petrographic studies indicated that three types of fluid inclusions, including primary, secondary, and pseudo secondary ones, exist in fluorite samples. The primary fluid inclusions dimension varies from 10 to $70 \mu \mathrm{m}$ in diameter. These fluid inclusions have different shapes such as the negative, elongated, irregular, spherical, circular, and square. The secondary and pseudo secondary fluid inclusions were also distinguished in the studied samples as two phases (L-V) and monophasic (L). These fluid inclusions have less than $8 \mu \mathrm{m}$ diameters which was developed along with the micro fractures of fluorite samples.
The micro thermometric results revealed that the first ice melting temperature, known as eutectic temperature $(\mathrm{Te})$, in the study district vary between $52 /-17.8^{\circ} \mathrm{C}$, respectively. All of these data indicated that the eutectic temperature of the studied fluorite samples was far below the eutectic temperature of $\mathrm{NaCl}-\mathrm{H}_{2} \mathrm{O}$ system (Bakker and Doppler, 2016), which can be due to the existence of some other salts such as $\mathrm{CaCl}_{2}\left(-52^{\circ} \mathrm{C}\right)$ and perhaps $\mathrm{MgCl}_{2}\left(-35^{\circ} \mathrm{C}\right)$ as well as $\mathrm{NaCl}-\mathrm{H}_{2} \mathrm{O}$ in hydrothermal fluids responsible for the formation of fluorite in these districts (Rddad and Bouhlel, 2016; Rezaei Azizi et al., 2018a; Rezaei Azizi et al., 2018b) (Fig. 6a). Previous studies indicated that the similarity between mineral assemblages in fluorite mineralization was an indicator of fluid composition rather than the existence of different fluids during fluorite precipitations (Margoum et al., 2015). These hypotheses indicate that the compositions of fluids responsible for fluorite mineralization in these districts were likely constant, but fluorite was likely deposited in different stages (Bosze and Rakovan, 2002).

The homogenization temperature $\left(\mathrm{T}_{\mathrm{H}}\right)$ of fluorite hosted fluid inclusions are in the range of $140-181^{\circ} \mathrm{C}$, respectively (Table. 1). Meanwhile, the salinity values for fluid inclusions at the same districts also vary between 2.4-13.49, 7.9-20.8 and 18.9-23.5 wt. \% $\mathrm{NaCl}$ 
equivalent, respectively. Figure 6a displays the homogenization temperature $\left(\mathrm{T}_{\mathrm{H}}\right)$ of fluid inclusions versus the salinity values of them. According to this figure, the overall trend of scattered pattern implies that isothermal mixing of hydrothermal fluids with meteoritic origin waters was likely being the most significant factor during fluorite deposition under stable conditions in these districts (Vinokurov et al., 2014). Another characteristic of fluid inclusion in this area is that fluorite mineralization can be divided into two different stages.

First stage fluorite mineralization was likely deposited from magmatic origin fluids, characterized by higher salinity values. In contrast, the second generation fluorites were probably deposited from low salinity fluids of meteoritic/hydrothermal origin fluids (Rezaei Azizi et al., 2018b). F-rich, low pH uprising fluids with higher salinity interacted with surrounding carbonate rock and saturated with $\mathrm{Ca}$ and finally caused the deposition of fluorite along structural pathways. The depth versus homogenization temperature diagram for fluorite mineralization in the study districts (Haas, 1971; Fig. 6b) revealed that the depth of fluorite deposition is situated between 33$256 \mathrm{~m}$. The hydrothermal deposits are generally reported from shallow, deep (less than $1 \mathrm{~km}$ ) geological environments from fluids with less than $300{ }^{\circ} \mathrm{C}$ (Wilkinson, 2001). This means that fluorite deposits in the study district can be classified as hydrothermal deposits.

\section{CONCLUSION}

The fluorite deposition is an interesting instance of the interaction between structures, host rock lithology, geochemical properties of hydrothermal fluid, temperature, depth, and several other parameters in the mineralization. The structural analysis in the studied district revealed that the structures such as fractures and veins are fault related. Deformation accommodated in a different phase. F-rich hydrothermal fluids flow in the fractures and altered country rocks. Several methods applied to the discrimination of alteration zones associated with fluorite mineralization. In the Laal-kan fluorite deposit, formation of fluorite accompanied by propylitic and phyllic alterations. Micro thermometry of fluid inclusion also indicated that the maximum homogenous temperature is (158-253), these data imply the temperature of hydrothermal fluid has an important role in the propagation of the alteration zones. The depth versus homogenization temperature diagram for fluorite mineralization revealed that the depth of fluorite deposition varies between 33 to $256 \mathrm{~m}$. Two generations of fluorite in the studied district is controlled by structures, the first generation derived from low-temperature-high salinity hydrothermal fluid and deposited in deeper level that are the fault-related, and the second generation of fluorite source is low salinity fluid of hydrothermal and meteorite water deposited in the low depth and are fracture-related.

\section{ACKNOWLEDGEMENT}

This work was supported financially by the Research Bureau of Urmia University. The authors would like to express their thanks and gratitude to the authorities of this bureau.

\section{REFERENCES}

Abdeen, M.M., Thurmond, A.K., Abdelsalam, M.G. and Stern, R.J.: 2001, Application of ASTER band-ratio images for geological mapping in arid regions: the neoproterozoic Allaqi Suture, Egypt. In: Proceedings of GSA 2001, Annual Meeting. Boston.

Agard, P., Omrani, J., Jolivet, L., Whitechurch, H., Vrielynck, B., Spakman, W., Monié, P., Meyer, B. and Wortel, R.: 2011, Zagros orogeny: a subductiondominated process. Geol. Mag., 148, 692-725. DOI: $10.1017 /$ S001675681100046X

Alavi, M.: 1991, Sedimentary and structural characteristics of the Paleo-Tethys remnants in northeastern Iran. Geol. Soc. Am. Bull., 103, 983-992.

DOI: $10.1130 / 0016-7606(1991) 103$

Alavi, M.: 1994, Tectonics of the Zagros orogenic belt of Iran: new data and interpretations. Tectonophysics, 229, 211-238. DOI: 10.1016/0040-1951(94)90030-2

Alipour, S., Abedini, A. and Talaie, B.: 2015, Geochemical characteristics of the Qahr-Abad fluorite deposit, southeast of Saqqez, western Iran. Arab. J. Geosci., 8, 7309-7320. DOI: $10.1007 / \mathrm{s} 12517-014-1747-6$

Aliyari, F., Rastadm E. and Mohajjel, M.: 2012, Gold deposits in the Sanandaj-Sirjan zone: Orogenic gold deposits or intrusion-related gold systems? Resour. Geol., 62, 296-315.

DOI: $10.1111 / j .1751-3928.2012 .00196 . x$

Alizadeh-Dinabad, H., Ghavami-Riabi, R., Eslamkish, T. and Mirzaeian, Y.: 2013, Controlling factors on changes of gold mineralization in Saqqez (Kurdistan) shear zones and reagent ratios of the mineralized section. Arab. J. Geosci., 6, 1457-1464. DOI: $10.1007 / \mathrm{s} 12517-011-0450-0$

Allen, M.B. and Amstrong, H.A.: 2008, Arabia-Eurasia collision and the forcing of mid-Cenozoic global cooling. Palaeogeogr. Palaeclimatol. Palaeoecol., 265, 52-68. DOI: 10.1016/j.palaeo.2008.04.021

Allen, M.B., Kheirkhah, M., Emami, M.H. and Jones, S.: 2010, Right-lateral shear across Iran and kinematic change in the Arabia-Eurasia collision zone. Geophys. J. Int., 184, 555-574. DOI: 10.1111/j.1365-246X.2010.04874.x

Almasi, A., Yousefi, M. and Carranza, E.J.M.: 2017, Prospectivity analysis of orogenic gold deposits in Saqez-Sardasht Goldfield, Zagros Orogen, Iran. Ore Geol. Rev., 91, 1066-1080. DOI: 10.1016/j.oregeorev.2017.11.001

Amer, R., Kusky, T. and Ghulam, A.: 2010, New methods of processing ASTER data for lithological mapping: examples from Fawakhir, Central Eastern Desert of Egypt. J Afr Earth Sci, 56, 75-82. DOI: 10.1016/j.jafrearsci.2009.06.004

Azizi, H., Hadad, S., Stern, R.J. and Asahara, Y.: 2018, Age, geochemistry, and emplacement of the $\sim 40$-Ma Baneh granite-appinite complex in a transpressional tectonic regime, Zagros suture zone, northwest Iran. Int. Geol. Rev., 61, 1-29.

DOI: $10.1080 / 00206814.2017 .1422394$ 
Azizi, H., Najari, M., Asahara, Y., Catlos, E.J., Shimizu, M. and Yamamoto, K.J.T.: 2015, U-Pb zircon ages and geochemistry of Kangareh and Taghiabad mafic bodies in northern Sanandaj-Sirjan Zone, Iran. Evidence for intra-oceanic arc and back-arc tectonic regime in Late Jurassic. Tectonophysics, 660, 47-64. DOI: $10.1016 /$ j.tecto.2015.08.008

Badr, A., Davoudian, A.R., Shabanian, N., Azizi, H., Asahara, Y., Neubauer, F., Dong, Y. and Yamamoto, K.J.L.: 2018, A-and I-type metagranites from the North Shahrekord Metamorphic Complex, Iran: Evidence for Early Paleozoic post-collisional magmatism. Lithos, 300, 86-104. DOI: 10.1016/j.lithos.2017.12.008

Baharvandi, A., Lotfi, M., Ghaderi, M., Jafari, M. and Tajeddin, H.: 2017, Ore mineralization and fluid inclusion and sulfur isotope studies on the Shekarbeig deposit, southwest Mahabad, Sanandaj-Sirjan zone. ULUM-I-ZAMIN, 26, 201-218. DOI: $10.22071 / \mathrm{gsj} .2017 .46614$

Bakker, R.J. and Doppler, G.: 2016, Salinity and density modifications of synthetic $\mathrm{H} 2 \mathrm{O}$ and $\mathrm{H} 2 \mathrm{O}-\mathrm{NaCl}$ fluid inclusions in re-equilibration experiments at constant temperature and confining pressure. Chem. Geol., 424, 73-85. DOI: 10.1016/j.chemgeo.2016.01.014

Behyari, M. and Kanabi, A.: 2019, Constraining of strain ellipsoid shape from sectional data in the au bearing shear zone west of Iran. Acta Geodyn. Geomater., 16, 131-143. DOI: 10.13168/AGG.2019.0010

Behyari, M., Rahimsouri, Y., Hoseinzadeh, E. and Kurd, N.: 2019, Evaluating of lithological and structural controls on the barite mineralization by using the remote sensing, Fry and fractal methods, Northwest Iran. Arab. J. Geosci., 12, 167. DOI: $10.1007 / \mathrm{s} 12517-019-4298-\mathrm{z}$

Behyari, M. and Shahbazi, M.: 2019, Strain and vorticity analysis in the Zagros suture zone (W Iran): Implications for Neo-Tethys post-collision events. J. Struct. Geol., 126, 198-209. DOI: $10.1016 /$ j.jsg.2019.06.002

Berberian, M. and King, G.C.P.: 1981, Towards a paleogeography and tectonic evolution of Iran. Can. J. Earth Sci., 5, 101-117. DOI: 10.1139/e81-019

Bosze, S. and Rakovan, J.: 2002, Surface-structurecontrolled sectoral zoning of the rare earth elements in fluorite from Long Lake, New York, and Bingham, New Mexico, USA. Geochim. Cosmochim. Acta, 66, 997-1009. DOI:1 0.1016/S0016-7037(01)00822-5

Crosta, A., De Souza Filho, C., Azevedo, F. and Brodie, C.: 2003 Targeting key alteration minerals in epithermal deposits in Patagonia, Argentina, using ASTER imagery and principal component analysis. Int. J. Remote Sens., 24, 4233-4240. DOI: $10.1080 / 0143116031000152291$

Daliran, F., Armstrong, R., Borg, G., Friese, K., Sadeghi, M., Vennemann, T., Walther, J. and Woodhead, J.: 2009, Nonsulphide zinc deposits, Iran-the hypogene emplacement and supergene modification history of the angouran zinc deposit, NW-Iran. Bundesanstalt für Geowissenschaften und Rohstoffe.

Daliran, F., Pride, K., Walther, J., Berner, Z.A. and Bakker, R.J.: 2013, The Angouran $\mathrm{Zn}(\mathrm{Pb})$ deposit, NW Iran: evidence for a two stage, hypogene zinc sulfide-zinc carbonate mineralization. Ore Geol Rev., 53, 373-402. DOI: 10.1016/j.oregeorev.2013.02.002
Di Tommaso, I. and Rubinstein, N.: 2007, Hydrothermal alteration mapping using ASTER data in the Infiernillo porphyry deposit, Argentina. Ore Geol. Rev., 32, 275-290. DOI: 10.1016/j.oregeorev.2006.05.004

Djamour, Y., Vernant, P., Nankali, H. and Tavakoli, F.: 2011, NW Iran-eastern Turkey present-day kinematics: Results from the Iranian permanent GPS network. Earth Planet. Sci. Lett., 307, 27-34. DOI: 10.1016/j.eps1.2011.04.029

Ehya, F. and Mazraei, S.M.: 2017, Hydrothermal barite mineralization at Chenarvardeh deposit, Markazi Province, Iran: Evidences from REE geochemistry and fluid inclusions. J. Afr. Earth Sci., 134, 299-307. DOI: 10.1016/j.jafrearsci.2016.11.006

Fang, Y., Zou, H., Bagas, L., Said, N., Li, Y. and Liu, H.: 2020, Fluorite deposits in the Zhejiang Province, southeast China: The possible role of extension during the late stages in the subduction of the Paleo-Pacific oceanic plate, as indicated by the Gudongkeng fluorite deposit. Ore Geol. Rev., 117, 103276.

DOI: 10.1016/j.oregeorev.2019.103276

Fischer, M.P., Higuera-Díaz, I.C., Evans, M.A., Perry, E.C. and Lefticariu, L.: 2009, Fracture-controlled paleohydrology in a map-scale detachment fold: Insights from the analysis of fluid inclusions in calcite and quartz veins. J. Struct. Geol., 31, 1490-1510. DOI: $10.1016 /$ j.jsg.2009.09.004

Gabr, S., Ghulam, A. and Kusky, T.: 2010, Detecting areas of high-potential gold mineralization using ASTER data. Ore Geol. Rev., 38, 59-69. DOI: $10.1016 /$ j.jsg.2009.09.004

Ghasemi, A. and Talbot, C.J.: 2006, A new tectonic scenario for the Sanandaj-Sirjan Zone (Iran). J. Asian Earth Sci., 26, 683-693. DOI:10.1016/j.jseaes.2005.01.003

Gilg, H.A., Boni, M., Balassone, G., Allen, C.R., Banks, D. and Moore, F.: 2006a, Marble-hosted sulfide ores in the Angouran $\mathrm{Zn}-(\mathrm{Pb}-\mathrm{Ag})$ deposit, NW Iran: interaction of sedimentary brines with a metamorphic core complex. Miner. Deposita, 41, 1-16. DOI: $10.1007 / \mathrm{s} 00126-005-0035-5$

Girouard, G., Bannari, A., El Harti, A. and Desrochers, A.: 2004, Validated spectral angle mapper algorithm for geological mapping: comparative study between QuickBird and Landsat-TM. In: XXth ISPRS Congress, geo-imagery bridging continents, Istanbul, Turkey, 12-23.

Haas, J.L.: 1971, The effect of salinity on the maximum thermal gradient of a hydrothermal system at hydrostatic pressure. Econ. Geol., 66, 940-946. DOI: 10.2113/gsecongeo.66.6.940

Hamdi, B.J.: 1995, Precambrian-Cambrian deposits in Iran. Treatise on the Geology of Iran, 20, 304 pp, (in Pharsi with, English summary).

Hassanzadeh, J., Stockli, D.F., Horton, B.K., Axen, G.J., Stockli, L.D., Grove, M., Schmitt, A.K. and Walker, J.D.: 2008, U-Pb zircon geochronology of late Neoproterozoic-Early Cambrian granitoids in Iran: Implications for paleogeography, magmatism, and exhumation history of Iranian basement. Tectonophysics, 451, 71-96. DOI: $10.1016 /$ j.tecto.2007.11.062

Jébrak, M.: 1997, Hydrothermal breccias in vein-type ore deposits: a review of mechanisms. Morphology and size distribution. Ore Geol. Rev., 12, 111-134. DOI: $10.1016 / \mathrm{S} 0169-1368(97) 00009-7$ 
Kraemer, D., Viehmann, S., Banks, D., Sumoondur, A.D., Koeberl, C. and Bau, M.: 2019, Regional variations in fluid formation and metal sources in MVT mineralization in the Pennine Ore field, UK: Implications from rare earth element and yttrium distribution, $\mathrm{Sr}-\mathrm{Nd}$ isotopes and fluid inclusion compositions of hydrothermal vein fluorites. Ore Geol. Rev., 107, 960-972.

DOI: 10.1016/j.oregeorev.2019.03.014

Magotra, R., Namga, S., Singh, P., Arora, N. and Srivastava, P.: 2017, A new classification scheme of fluorite deposits. Int. J. Geosci., 8, 599-610. DOI: 10.4236/ijg.2017.84032

Margoum, D., Bouabdellah, M., Klügel, A., Banks, D.A., Castorina, F., Cuney, M., Jébrak, M. and Bozkaya, G.: 2015, Pangea rifting and onward pre-Central Atlantic opening as the main ore-forming processes for the genesis of the Aouli REE-rich fluorite-barite vein system, upper Moulouya district, Morocco. J. Afr. Earth Sci., 108, 22-39.

DOI: $10.1016 /$ j.jafrearsci.2015.03.021

Moghadam, H.S., Khademi, M., Hu, Z., Stern, R.J., Santos, J.F., Wu, Y.: 2015, Cadomian (Ediacaran-Cambrian) arc magmatism in the ChahJam-Biarjmand metamorphic complex (Iran). Magmatism along the northern active margin of Gondwana. Gondwana Res., 27, 439-452. DOI: 10.1016/j.gr.2013.10.014

Moghadam, H.S., Li, X.-H., Stern, R.J., Ghorbani, G. and Bakhshizad, F.: 2016, Zircon U-Pb ages and Hf-O isotopic composition of migmatites from the ZanjanTakab complex, NW Iran: constraints on partial melting of metasediments. Lithos, 240, 34-48. DOI: $10.1016 /$ j.lithos.2015.11.004

Mohajjel, M. and Fergusson, C.L.: 2000, Dextral transpression in Late Cretaceous continental collision, Sanandaj-Sirjan zone, western Iran. J. Struct. Geol., 22, 1125-1139. DOI: $10.1016 / \mathrm{S} 0191-8141(00) 00023-7$

Mohajjel, M. and Rasouli, A.: 2014, Structural evidence for superposition of transtension on transpression in the Zagros collision zone: Main recent fault, Piranshahr area, NW Iran. J. Struct. Geol., 62, 65-79.

DOI: $10.1016 /$ j.jsg.2014.01.006

Mouthereau, F., Lacombe, O. and Vergés, J.: 2012, Building the Zagros collisional orogen: timing, strain distribution and the dynamics of Arabia/Eurasia plate convergence. Tectonophysics, 532, 27-60.

DOI: $10.1016 /$ j.tecto.2012.01.022

Parsa, M., Maghsoudi, A., Yousefi, M. and Sadeghi, M.: 2016, Recognition of significant multi-element geochemical signatures of porphyry $\mathrm{Cu}$ deposits in Noghdouz area, NW Iran. J. Geochem. Explor., 165, 111-124. DOI: 10.1016/j.gexplo.2016.03.009

Rajendran, S., Al-Khirbash, S., Pracejus, B., Nasir, S., AlAbri, A.H., Kusky, T.M. and Ghulam, A.: 2012, ASTER detection of chromite bearing mineralized zones in Semail Ophiolite Massifs of the northern Oman Mountains: Exploration strategy. Ore Geol. Rev., 44, 121-135.

DOI: 10.1016/j.oregeorev.2011.09.010

Ramli, M., Yusof, N., Yusoff, M., Juahir, H., Shafri, H.J. and Boe, G.: 2010, Lineament mapping and its application in landslide hazard assessment. a review. Bull. Eng. Geol. Environ., 69, 215-233.

DOI: $10.1007 / \mathrm{s} 10064-009-0255-5$
Rddad, L. and Bouhlel, S.: 2016, The Bou Dahar Jurassic carbonate-hosted $\mathrm{Pb}-\mathrm{Zn}-\mathrm{Ba}$ deposits (Oriental High Atlas, Morocco): Fluid-inclusion and $\mathrm{C}-\mathrm{O}-\mathrm{S}-\mathrm{Pb}$ isotope studies. Ore Geol. Rev., 72, 1072-1087. DOI: 10.1016/j.oregeorev.2015.08.011

Rezaei Azizi, M., Abedini, A., Alipour, S. and Bagheri, H.: 2018a, The Laal-Kan fluorite deposit, Zanjan Province, NW Iran: constraints on REE geochemistry and fluid inclusions. Arab. J. Geosci., 11, 719. DOI: 10.1007/s12517-018-4055-8

Rezaei Azizi, M., Alipour, S., Abedini, A. and Bagheri, H.: 2018b, REE geochemical characteristics and fluid inclusion studies of the Bagher-Abad fluorite deposit, Central Iran. Neues Jahrbuch für Mineralogie Abhandlungen: Journal of Mineralogy and Geochemistry, 195, 247-263 DOI: $10.1127 / \mathrm{njma} / 2018 / 0124$

Rezaei Azizi, M., Abedini, A., Alipour, S., Niroomand, .S, Sasmaz, A. and Talaei, B.: 2017, Rare earth element geochemistry and tetrad effects in fluorites. A case study from the Qahr-Abad deposit, Iran. Neues Jahrbuch für Geologie und Paläontologie Abhandlungen, 283, 255-273. DOI: $10.1127 /$ njgpa/2017/0639

Richardson, C.K. and, Holland, H.: 1979, Fluorite deposition in hydrothermal systems. Geochim. Cosmochim. Acta, 43, 1327-1335. DOI: $10.1016 / 0016-7037(79) 90122-4$

Saki, A.J.G.R.: 2010, Proto-Tethyan remnants in northwest Iran. Geochemistry of the gneisses and metapelitic rocks. Gondwana Res., 17, 704-714. DOI: $10.1016 /$ j.gr.2009.08.008

Sarkarinejad, K. and Azizi, A.: 2008, Slip partitioning and inclined dextral transpression along the Zagros Thrust System, Iran. J. Struct. Geol., 30, 116-136. DOI: 10.1016/j.jsg.2007.10.001

Shahriari, H., Honarmand, M. and Ranjbar, H.: 2015, Comparison of multi-temporal ASTER images for hydrothermal alteration mapping using a fractal-aided SAM method. Int. J. Remote Sens., 36, 1271-1289. DOI: 10.1080/01431161.2015.1011352

Tangestani, M.H., Jaffari, L., Vincent, R.K. and Sridhar, B.M.: 2011, Spectral characterization and ASTERbased lithological mapping of an ophiolite complex: A case study from Neyriz ophiolite, SW Iran. Remote Sens. Environ., 115, 2243-2254. DOI: $10.1016 /$ j.rse.2011.04.023

Thannoun, R.G.: 2013, Automatic extraction and geospatial analysis of lineaments and their tectonic significance in some areas of Northern Iraq using remote sensing techniques and GIS. IJERSTE, 2. DOI: 10.13140/RG.2.2.20851.99363

Uras, Y., Nikiforov, A.V., Oner, F. and Parlak, O.: 2017, Geochemistry and $\mathrm{Nd}, \mathrm{Sr}$ isotopes of the Pohrenk fluorites (Kursehir-Turkey). Geochem. Int., 55, 263281. DOI: $10.1134 /$ S0016702917030090

Vernant, P., Nilforoushan, F., Hatzfeld, D., Abbassi, M., Vigny, C., Masson, F., Nankali, H., Martinod, J., Ashtiani, A. and Bayer, R.: 2004, Present-day crustal deformation and plate kinematics in the Middle East constrained by GPS measurements in Iran and northern Oman. Geophys. J. Int., 157, 381-398. DOI: $10.1111 / \mathrm{j} .1365-246 X .2004 .02222 . x$ 
Vinokurov, S., Golubev, V., Krylova, T., Prokof'ev, V.Yu..: 2014, REE and fluid inclusions in zoned fluorites from Eastern Transbaikalia. Distribution and geochemical significance. Geochem. Int., 52. 654-669. DOI: $10.1134 / \mathrm{S} 0016702914060093$

Watts, M. and Williams, G.: 1983, Strain geometry, microstructure and mineral chemistry in metagabbro shear zones: a study of softening mechanisms during progressive mylonitization. J. Struct. Geol., 5, 507517. DOI: 10.1016/0191-8141(83)90056-1

Wilkinson, J.J.L.: 2001, Fluid inclusions in hydrothermal ore deposits. Lithos, 55, 229-272. DOI: $10.1016 / \mathrm{S} 0024-4937(00) 00047-5$

Zarasvandi, A., Rezaei, M., Sadeghi, M., Lentz, D., Adelpour, M. and Pourkaseb, H.: 2015, Rare earth element signatures of economic and sub-economic porphyry copper systems in Urumieh-Dokhtar Magmatic Arc (UDMA), Iran. Ore Geol. Rev., 70, 407-423. DOI: 10.1016/j.oregeorev.2015.01.010

Zarasvandi, A., Zaheri, N., Pourkaseb, H., Chrachi, A. and Bagheri, H.: 2014, Geochemistry and fuid-inclusion microthermometry of the Farsesh Barite Deposit, Iran. Geologos, 20, 201-214.

DOI: $10.2478 / \log$ os-2014-0015

Zhang, Z., Xiao, W., Ji, W., Majidifard, M.R., Rezaeian, M., Talebian, M., Xiang, D., Chen, L., Wan, B. and Ao, S. 2018, Geochemistry, zircon U-Pb and Hf isotope for granitoids, NW Sanandaj-Sirjan zone, Iran: Implications for Mesozoic-Cenozoic episodic magmatism during Neo-Tethyan lithospheric subduction. Gondwana Res. 62, 227-245. DOI: 10.1016/j.gr.2018.04.002

Zou, H., Fang, Y., Zhang, S.T. and Zhang, Q.: 2017, The source of Fengjia and Langxi barite-fluorite deposits in southeastern Sichuan, China. Evidence from rare earth elements and $\mathrm{S}, \mathrm{Sr}$, and $\mathrm{Sm}-\mathrm{Nd}$ isotopic data. Geol. J., 52, 470-488. DOI: 10.1002/gj.2779

Zou, H., Li, M., Bagas, L., Li, Y., Fang, Y., Cao, H-W., Jiang, X-W. and Chen, H-F.: 2020a, Fluid composition and evolution of the Langxi Ba-F deposit, Yangtze Block, China. New Insight from LA-ICP-MS study of individual fluid inclusion. Ore Geol. Rev., 125, 103702. DOI: 10.1016/j.oregeorev.2020.103702

Zou, H., Pirajno, F., Zhang, Q., Tessalina, S., Ware, B., Li, X-y., Liu, H., Li, Y., Jiang, X-w. and Wei, S-yi.: 2020b, New evidence from the Wuliji'Oboo fluorite deposit for the role of the paleo-Pacific Plate and Mongol-Okhotsk suture in creating extensive fluorite mineralization in the Great Xing'an Range, NE China. Geol. J., 55, 3654-3678. DOI: 10.1002/gj.3601

Zou, H., Zhang, S-t., Chen, A-q., Fang, Y. and Zeng, Z-f.: 2016, Hydrothermal fluid sources of the Fengiia barite-fluorite deposit in southeast Sichuan, China: evidence from fluid inclusions and hydrogen and oxygen isotopes. Resour. Geol., 66, 24-36.

DOI: $10.1111 /$ rge. 12084 